\title{
Muzułmanie we wspótczesnej Rosji: media i kultura
}

\begin{abstract}
Artykuł omawia rozwój, aktywność oraz wpływ wywierany przez rosyjską społeczność muzułmańską w sferze medialnej i kulturowej na obszarze Federacji Rosyjskiej. Autor argumentuje, że jest ona obecnie społecznością coraz liczniejszą oraz coraz bardziej wpływową, zaś jej rozwój postrzegać można jako jeden z najważniejszych rezultatów odrodzenia religijnego w Rosji.
\end{abstract}

Słowa kluczowe: islam, Rosja, społeczność muzułmańska, kultura, media, religie w Rosji

Swoboda wyznania i kultu religijnego była jednym z ważniejszych elementów pierestrojki, a więc jednym z kierunków rozwoju Rosji na przełomie lat osiemdziesiątych i dziewięćdziesiątych XX wieku. Ustanowienie wolności religijnej rozpatrywać można $\mathrm{z}$ jednej strony jako element liberalizacji reżimu sowieckiego, a później, po rozpadzie ZSRR - jako element demokratyzacji. Za symboliczną datę renesansu religijnego w Rosji przyjąć można rok 1988, kiedy to na poziomie ogólnopaństwowym obchodzono jubileusz tysięcznej rocznicy oficjalnego chrztu Rusi ${ }^{1}$. 25 października 1990 roku Rada Najwyższa ZSRR przyjęła ustawę „O wolności wyznañ”, która zrównała pod względem prawnym wszystkie wyznania, natomiast artykuł 14 konstytucji Federacji Rosyjskiej z 1993 roku stwier-

\footnotetext{
${ }^{1}$ А. Малашенко, Ислам «легализованный» и возрожденный,, [w:] Двадияать лет религиозной свободы в России, red. А. Малашенко, С. Филатов, Москва 2009, s. 245-247.

2 Постановление ВС РСФСР от 25.10.1990 n 268-1 о порядке введения в действие закона РСФСР „О свободе вероисповеданий”, http://pravo.levonevsky.org/baza/soviet/sssr0655.htm [dostęp: 25.11.2015].
} 
dzał, iż ,żadna religia nie może być uznana za państwową lub obowiązującą”. Dodatkowo ustawa „O wolności sumienia i związkach wyznaniowych” z 1997 roku uznawała, iż prawosławie, islam, judaizm i buddyzm są integralną częścią historycznego dziedzictwa Rosji ${ }^{3}$, a także wymagała od innych grup wyznaniowych poddania się złożonym procedurom rejestracyjnym, umożliwiającym ich działalność na terenie kraju. Pomimo krytyki samej ustawy na arenie międzynarodowej jako naruszającej wolność wyznania, jej orędownicy przekonywali, iż zapisy takie są niezbędne, by powstrzymać zorganizowane i dysponujące szerokim zapleczem finansowym ruchy wyznaniowe przed szkodliwym dla tradycyjnych religii wypełnieniem próżni powstałej w wyniku sowieckiej polityki antyreligijnej ${ }^{4}$.

Islam w dzisiejszej Rosji z pewnością nie jest jednolity. Należy w pierwszej kolejności zwrócić uwagę na pojawiający się coraz częściej w ostatnich latach podział na islam tradycyjny i nietradycyjny. Do tradycyjnego islamu zaliczyć można te grupy muzułmanów, które pojawiły się w Rosji i zbudowały swoją tożsamość jeszcze przed rewolucją i istnieją do dziś. Islam nietradycyjny to w głównej mierze grupy, które pojawiły się w Rosji po 1991 roku i głoszą konieczność odnowy religii, jej swoistego oczyszczenia. Rosyjscy muzułmanie to przede wszystkim Tatarzy, Baszkirzy i mieszkańcy Północnego Kaukazu. Według ostatniego spisu ludności Rosję zamieszkuje 14,5 miliona wyznawców tradycyjnego islamu. Większość rosyjskich muzułmanów to sunnici szkoły hanafickiej. Jedynie na Kaukazie obecna jest również szkoła szaficka; rozpowszechniony jest tam także sufizm. W siedmiu podmiotach federalnych muzułmanie stanowią większość ludności. Są to: Inguszetia - 98\%, Czeczenia - 96\%, Dagestan - 94\%, Kabardyno-Bałkaria - 70\%, Karaczajo-Czerkiesja - 63\%, Baszkortostan - 54,5\%, Tatarstan - 54\%. W samej Moskwie liczba muzułmanów sięga 2 milionów, a w obwodzie moskiewskim - 650 tysięcy ${ }^{5}$.

Federację Rosyjską zamieszkują także muzułmańscy imigranci, których liczba wciąż wzrasta. Są to głównie przybysze z Azji Centralnej - Uzbekistanu, Kirgistanu i Tadżykistanu, a także z Afganistanu. Ich liczbę szacuje się od ponad miliona do nawet 3,5 miliona. Sytuacja związana ze strukturą i demografią dotyczącą ludności muzułmańskiej w Rosji wydaje się być zatem dość złożona. Według wybitnego rosyjskiego uczonego, eksperta Centrum Badań nad Azją Centralną, Kaukazem, Uralem i Powołżem Rosyjskiej Akademii Nauk - profesora Michaiła Roszczyna - władze rosyjskie stoją dziś przed znaczącym wyzwaniem i starają się wyjść mu naprzeciw poprzez m.in. wspieranie - głó-

\footnotetext{
3 J. Krukowski, Konstytucyjne modele stosunków między państwem a Kościolem w Europie, http://www.pan-ol.lublin.pl/biul 9/art 907.htm [dostęp: 25.11.2015].

${ }^{4}$ N.V. Riasanovsky, M.D. Steinberg, Historia Rosji, Kraków 2009, s. 706.

${ }^{5}$ А. Малашенко, Ислам для России, Москва 2006, s. 11.
} 
wnie finansowe - tradycyjnego islamu ${ }^{6}$. Zdaniem uczonego również nietradycyjny, radykalny islam rośnie w siłę, pomimo braku finansowania ze strony państwa. Wszędzie tam, gdzie istnieje stosunkowo silne zbrojne podziemie (w Dagestanie, Inguszetii czy Kabardyno-Bałkarii) fundusze pozyskiwane są z haraczy, gdyż finansowanie $\mathrm{z}$ zewnątrz jest coraz trudniejsze ze względu na coraz większą przejrzystość systemów bankowych ${ }^{7}$.

Rosyjski islam nie jest jednolity również pod względem strukturalno-organizacyjnym. $Z$ pewnością nie można nazwać go religią scentralizowaną - nie ma osoby stojącej na jej czele, nie ma również jednej, uniwersalnej wykładni wiary. Rosyjscy muzułmanie w opinii imama Głównego Meczetu Moskwy - Rawiła Gajnutdina - dzielą się na trzy podstawowe grupy w zależności od regionu, w którym mieszkają. Pierwsza, oddalona od centrum, to przede wszystkim muzułmanie Dalekiego Wschodu i Syberii, druga obejmuje centralne obszary kraju - Powołże, Ural, Moskwę, etc., zaś trzecią stanowi ludność Północnego Kau$\mathrm{kazu}^{8}$.

Znaczna większość Rosjan kształtuje swoją opinię na temat islamu i muzułmanów pod wpływem przekazów dostarczanych przez media. Jak zauważa profesor Aleksej Małaszenko z moskiewskiego Centrum Carnegie, stosunkowo szybkie wykrystalizowanie się $\mathrm{w}$ latach dziewięćdziesiątych XX wieku negatywnego wizerunku wyznawców Allaha zarówno w mediach, jak i wśród samego rosyjskiego społeczeństwa, spowodowane było przede wszystkim przez konflikty, w których uczestniczyli muzułmanie, a także wzrost nastrojów nacjonalistycznych wśród narodów muzułmańskich oraz aktywność terrorystów. Te trzy główne przyczyny badacz określa mianem obiektywnego czynnika rozwoju islamofobii w Rosji. Subiektywnym czynnikiem rozwoju nastrojów antymuzułmańskich wśród rosyjskiego było natomiast przypisywanie określonym wydarzeniom z udziałem muzułmanów (jak na przykład wojna w Czeczenii) wyjątkowego znaczenia oraz przedstawianie ideologii ekstremistycznej jako cechy charakterystycznej całej religii muzułmańskiej ${ }^{9}$. Efektem tego był wzrost liczby publikacji prasowych i audycji, w których islam i muzułmanie pojawiali się w kontekście wojen, ataków terrorystycznych i konfliktów. Bez wątpienia negatywny stosunek do muzułmanów wśród społeczeństwa rosyjskiego wpisuje się w ogólnorosyjski kontekst postępującej ksenofobii - o ile jeszcze w roku 1989 do oznak ksenofobii przyznawało się zaledwie 20\% społeczeństwa, to w 2001 roku

\footnotetext{
${ }^{6}$ M. Roszczyn, Islam w Rosji: umma dopiero się rodzi, ,Nowa Europa Wschodnia” 2013, nr 3-4 (XXIX-XXX), s. 23-26.

${ }^{7}$ Tamże.

${ }^{8}$ Р. Гайнутдин, Ислам в Современной России, Москва 2004, s. 32-37.

${ }^{9}$ А. Малашенко, Ислам для..., s. 53-63.
} 
liczba ta przekroczyła już $50 \%{ }^{10}$. Tendencje te znajdują także odzwierciedlenie w najnowszych badaniach opinii publicznej - na zadane w kwietniu 2014 roku przez jedną z rosyjskich pracowni badań opinii publicznej pytanie „Jaką rolę Twoim zdaniem islam odgrywa dzisiaj w Rosji: pozytywną czy negatywną?" - 32\% ankietowanych wskazało, iż negatywną, a jedynie $25 \%$, że pozytywną ${ }^{11}$.

Współczesne relacje na linii islam-państwo porównać można do tych, które zachodziły na przestrzeni wieków, poczynając od XVIII stulecia do roku 1917, kiedy to władza państwowa starała się dążyć do konsensusu z muzułmanami, przy jednoczesnym zachowaniu nad nimi kontroli. W pewnym sensie dzisiejsze relacje między społecznością muzułmańską a władzą postrzegać można jako kontynuację tej tradycji. Utrzymywanie dobrych relacji ze społecznością muzułmańską przy jednoczesnym kompleksowym jej kontrolowaniu Kreml realizuje na wiele sposobów. Relacje - przynajmniej te oficjalne - władz państwowych z przedstawicielami społeczności muzułmańskiej określić można jako bardzo poprawne, a niekiedy wręcz przyjazne. W oficjalnych wypowiedziach zarówno premier, jak i prezydent Federacji Rosyjskiej podkreślają, iż islam (tradycyjny) stanowi integralną część rosyjskiej tożsamości ${ }^{12}$. Pozytywne podejście władz państwowych do kwestii muzułmańskiej nie ma jedynie czysto kurtuazyjnego wymiaru. Elita rządząca musi zdawać sobie sprawę tego, iż ze względu na wewnętrzną stabilność państwa i minimalizację nastrojów separatystycznych jakikolwiek konflikt z muzułmanami, którzy stanowią znaczący odsetek mieszkańców kraju, nie wchodzi w grę.

Najbardziej zauważalnym jest utrzymywanie dobrych relacji z kluczowymi przywódcami politycznymi w regionach. Jeżeli oprócz dobrych relacji występuje również dofinansowanie tychże regionów sporymi sumami $\mathrm{z}$ budżetu federalnego, powstać może obraz niemal idealnej współzależności. Doskonałym przykładem może być casus Czeczenii. Dla większości Czeczenów, zmęczonych wojnami, to, co dzieje się w republice w czasach rządów Ramzana Kadyrowa jest ważniejsze niż jego dyktatorskie ambicje. Lojalność w stosunku do Władimira Putina Kadyrow eksponuje z każdym rokiem urzędowania jako głowy Republiki coraz śmielej. Przykłady można wyliczać: jest to chociażby nazwanie jednej z głównych ulic w Groznym imieniem Władimira Putina, zorganizowanie w październiku 2014 roku stutysięcznego marszu w stolicy Czeczenii z okazji urodzin Putina, czy wypowiedzi Kadyrowa, w których wyraża on opinię, iż

\footnotetext{
${ }^{10}$ Tamże.

${ }^{11}$ Pozostałe 43\% badanych zadeklarowało, że nie ma zdania w tej kwestii. Ислам - «соседняя дружественная религия», http://fom.ru/TSennosti/12121 [dostęp: 25.11.2015].

${ }^{12}$ Выступление на торжественном собрании, посвящённом 225-летию Центрального духовного управления мусульман России, http://kremlin.ru/transcripts/19473 [dostęp: 25.11. 2015]
} 
Putin powinien sprawować swój urząd dożywotnio ${ }^{13}$. Warto również zaznaczyć, iż również przedstawiciele najważniejszych organizacji muzułmańskich działających w centralnej Rosji, na Powołżu czy Kaukazie, przy każdej możliwej okazji podkreślają lojalność wobec władzy państwowej i dezaprobatę wobec wszelkiej działalności ekstremistycznej ${ }^{14}$.

Niezwykle istotnym obszarem działalności rosyjskich muzułmanów jest sfera edukacji, w szczególności szkolnictwa wyższego. Kwesta edukacji jest jednym z najważniejszych, o ile nie najważniejszym czynnikiem wpływającym na kształt społeczności muzułmańskiej w Rosji. Stabilny i systematyczny rozwój rodzimej edukacji muzułmańskiej pozwala ograniczyć wpływy obcych dla rosyjskiego islamu ideologii. Od kilku lat działa powołany przy prezydencie Fundusz Wsparcia Muzułmańskiej Kultury, Nauki i Edukacji, który z politycznego punktu widzenia bez wątpienia służyć ma wzmocnieniu tradycyjnego islamu. Siedziba Funduszu znajduje się w Moskwie, jednym z jego założycieli jest Rada Muftich Rosji, a o prestiżu samej organizacji świadczy fakt, iż funkcję przewodniczącego rady nadzorczej wspomnianej organizacji sprawuje Jewgienij Primakow, były minister spraw zagranicznych Federacji Rosyjskiej. Fundusz wspiera projekty dotyczące rozwoju muzułmańskiej kultury, nauki, edukacji, a w szczególności te, dotyczące wypracowania jednolitych standardów kształcenia muzułmańskiego w Rosji, wypracowania programów nauczania dla instytucji edukacyjnych o charakterze szkół średnich i uczelni wyższych, a także przygotowania podręczników i literatury wykorzystywanej w procesie kształcenia ${ }^{15}$.

Postępujące zmiany społeczno-polityczne w Rosji na przełomie lat osiemdziesiątych i dziewięćdziesiątych XX wieku wywarły wpływ na niemal każdą dziedzinę życia i formę aktywności społecznej muzułmanów w tym kraju. W ciągu ostatniej dekady XX wieku, a także na początku nowego tysiąclecia, środki masowego przekazu sprzyjały odrodzeniu religijnemu w Rosji, obudziły w społeczeństwie zainteresowanie religią, można nawet stwierdzić, iż w pewnym sensie kształtowały one ,nowych wiernych" ${ }^{\prime \prime}$.

Pierwsze audycje telewizyjne poświęcone życiu muzułmanów sięgają początku lat dziewięćdziesiątych. Począwszy od roku 1992 z Głównego Meczetu Moskwy na terytorium całego kraju były transmitowane bezpośrednie relacje z najważniejszych muzułmańskich świąt - Kurban Bajram i Uraza Bajram. W tym samym

\footnotetext{
${ }^{13}$ W. Górecki, Dokąd zmierza Kaukaz Pótnocny, „Nowa Europa Wschodnia”, 2011, nr 6 (XX), s. 77-84.

${ }^{14}$ Соииальная доктрина российских мусульман, http://islam-today.ru/socialnaa-doktrina-ros sijskih-musulman/ [dostęp: 25.11.2015].

${ }^{15}$ О Фонде поддержки исламской культуры,науки и образования, http://www.islamfund.ru/ about.html [25.11.2015].

${ }^{16}$ А. Малашенко, Ислам для..., s. 62.
} 
czasie dzięki zaangażowaniu pracowników Muzułmańskiego Centrum w Moskwie na antenie państwowej rozgłośni radiowej zaczęto nadawać w języku tatarskim cotygodniową audycję o charakterze religijno-edukacyjnym Duchowe dziedzictwo. Natomiast w telewizji państwowej raz w miesiącu emitowano program „Minaret”, poświęcony życiu społeczności muzułmańskiej Moskwy i okolic rosyjskiej stolicy ${ }^{17}$. W roku 1994 wraz z powstaniem Duchownego Zarządu Muzułmanów Europejskiej Części Rosji ${ }^{18}$ raz w miesiącu zaczął ukazywać się periodyk poświęcony życiu muzułmanów „Islam Minbare” („Trybuna Islamu”).

W każdy piątek o godzinie 8.55 na antenie pierwszego kanału rosyjskiej telewizji państwowej „Rossija” nadawany jest program „Muzułmanie”. Dzięki niemu od ponad 11 lat widzowie mają okazję poznawać tradycję i kulturę muzułmańską, bo sam program, jak zaznaczają twórcy, nie ma charakteru czysto religijnego. Taka formuła pozwala na dostęp do szerokiego grona audytorium, które stanowią nawet ateiści. Program realizowany jest w całości ze środków budżetu federalnego, bez wsparcia sponsorów i bez przerw na reklamy. Co istotne, w programie nie porusza się kwestii związanych z polityką. Jego główną prezenterką jest Dinara Sadretdinowa - zasłużona artystka republiki Dagestanu, republiki Tatarstanu, Karaczajo-Czerkiesji i Inguszetii ${ }^{19}$.

Pierwszym profesjonalnym kanałem telewizyjnym skierowanym do muzułmanów w Rosji jest kanał Islam TV, który powstał w kwietniu 2007 roku, a swój program - w języku rosyjskim - emituje przez ponad 12 godzin na dobę. Właścicielem Islam TV jest koncern Islamskij Mir, powołany w roku $1997^{20}$. Program stacji transmitowany jest przez stronę internetową islamtv.ru, choć - jak zapewniają władze kanału - trwają intensywne prace nad uruchomieniem nadawania $\mathrm{w}$ formie satelitarnej, które miałoby docelowo objąć zasięgiem cały kraj oraz państwa $\mathrm{WNP}^{21}$. Gama audycji oferowanych widzom Islam TV jest bardzo różnorodna. W ofercie znajdują się programy dokumentalne, relacje z ważnych wydarzeń kulturalnych, audycje społeczno-polityczne, programy animowane dla

\footnotetext{
${ }^{17}$ Ф. Асадуллин, Ислам в Москве, Москва, s. 75-86.

${ }^{18}$ Duchowny Zarząd Muzułmanów Europejskiej Części Rosji (Духовное Управление мусульман Европейской части России) - organizacja utworzona w 1994 r., jeszcze w ramach Centralnego Duchownego Zarządu Muzułmanów w Rosji (najstarszej rosyjskiej organizacji muzułmańskiej, powstałej za czasów Katarzyny II), która zdobyła formalną niezależność od tej instytucji po kilku miesiącach funkcjonowania. Obejmuje swoją jurysdykcją muzułmańskie społeczności m.in. w Moskwie, Sankt Petersburgu, Niżnym Nowogrodzie, Twerze, Wołogdzie, Iwanowie, Tule, Soczi, Jarosławiu $\mathrm{i}$ innych. Jest niezależną strukturą, koordynuje jednak swoje działanie z innymi duchownymi zarządami.

${ }^{19}$ Мусульмане, http://russia.tv/brand/show/brand id/3959/ [dostęp: 25.11.2015].

20 3. Мамиргов, ТВК „Исламский Мир” (islamtv.ru), http://www.islamtv.ru/about.html [dostęp: 25.11.2015].

${ }^{21}$ Tamże.
} 
dzieci, debaty i dyskusje oraz programy poradnikowe. Koncern Islamskij Mir zajmuje się również działalnością wydawniczą, a także jest organizatorem międzynarodowych festiwali filmowych. Warto dodać, że jest on również producentem znacznej części programów emitowanych na kanale Islam TV, zapewniając im stosunkowo wysoki poziom merytoryczny ${ }^{22}$.

W sierpniu 2012 roku całodobowe nadawanie rozpoczęła stacja telewizyjna Al-RTV. Inicjatywa utworzenia muzułmańskiego kanału telewizyjnego została oficjalnie przedstawiona w sierpniu 2009 roku, kiedy to podczas konferencji „Rosja i świat muzułmański - partnerstwo dla stabilizacji” mufti Rawił Gajnutdin zwrócił się do władz z prośbą o wsparcie inicjatywy jego stworzenia. Al-RTV dociera do odbiorców w ośmiu podmiotach federalnych: Baszkortostanie, Tatarstanie, Dagestanie, Czeczenii, Republice Adygei, KabardoBałkarii, Karaczajo-Czerkiesji i Inguszetii. Al-RTV dostępny jest w pakiecie telewizji cyfrowej „Trikolor TV”, razem z kanałami prawosławnymi. Kanał w głównej mierze finansowany jest ze środków prywatnych (przedsiębiorców) oraz grantów federalnych ${ }^{23}$.

Koncern Islamskij Mir wspólnie z Radą Muftich Rosji ${ }^{24}$ jest również organizatorem jednego z najważniejszych muzułmańskich wydarzeń kulturalnych w Rosji - Kazańskiego Międzynarodowego Festiwalu Kina Muzułmańskiego, który każdego roku odbywa się w Kazaniu ${ }^{25}$. Sam pomysł zorganizowania takiej imprezy pojawił się $\mathrm{w}$ związku z tworzeniem nowego kanału muzułmańskiego (Islam TV), poszukiwano bowiem wartościowych produkcji, które mogłyby wypełnić czas antenowy. Festiwal miał być także platformą wymiany doświadczeń twórców kina, podejmujących w swych filmach problematykę muzułmańską, oraz miał za zadanie przedstawić społeczeństwu za pomocą sztuki filmowej pozytywny obraz muzułmanina. Co ważne, w festiwalu mogli uczestniczyć autorzy filmów, niekoniecznie będący wyznawcami islamu. Kazański Międzynarodowy Festiwal Kina Muzułmańskiego organizowany jest od 2005 roku. Pomysłodawcą Festiwalu jest Ministerstwo Kultury Republiki Tatarstanu oraz

\footnotetext{
${ }^{22}$ Tamże.

${ }^{23}$ В России начал вещание первый общественный мусульманский телеканал, http://lenta.ru/ news/2012/08/20/alrtv/ [dostęp: 25.11.2015].

${ }^{24}$ Rada Muftich Rosji (Совет муфтиев России) - organizacja utworzona w roku 1996 roku. W jej skład wchodzą przedstawiciele 20 duchownych zarządów i innych organizacji muzułmańskich. Głównym celem działalności Rady jest wypracowywanie wspólnych stanowisk i koordynowanie działań zarządów, dobrowolnie wchodzących w jej skład. Istotnym elementem działalności tej organizacji jest także wymiar edukacji - w jej ramach utworzono w 2005 roku Radę ds. Edukacji Muzułmańskiej.

25 Казанский международный фестиваль мусульманского кино, http://kazan-mfmk.com/ about-mfmk [25.11.2015].
} 
Rada Muftich Rosji. Patronem honorowym wydarzenia jest prezydent Republiki Tatarstanu ${ }^{26}$.

Od roku 1994 ukazuje się jeden z najbardziej opiniotwórczych i wartościowych periodyków skierowanych do społeczności muzułmańskiej Rosji - „Islam Minbare”. Tytuł ten, publikowany w języku rosyjskim, jest oficjalnym organem wydawniczym Duchownego Zarządu Muzułmanów Europejskiej Części Rosji oraz Rady Muftich Rosji ${ }^{27}$. Jak informuje wydawca, czasopismo zyskało sympatię i szacunek szerokiego grona czytelników za obiektywne przedstawianie realiów życia religijnego społeczności muzułmańskiej w Rosji ${ }^{28}$. Gazeta podaje także wiarygodne informacje o wydarzeniach związanych z działalnością scentralizowanych struktur muzułmańskich, jak również z problemami wiary, czy zagadnieniami dotyczącymi współpracy międzynarodowej. Na łamach wydawnictwa swoje artykuły publikują znane i cenione postaci rosyjskiej ummy, a także działacze polityczni i społeczni, tacy jak Mintimer Szajmijew ${ }^{29}$, czy Kamil Ishakow $^{30}$. „Islam Minbare” dużo uwagi poświęca także wydarzeniom kulturalnym, w tym problemom dialogu międzyreligijnego. Gazeta wydawana jest ze środków Duchownego Zarządu Muzułmanów Europejskiej Części Rosji i Rady Muftich Rosji i dostępna jest na całym terytorium Federacji Rosyjskiej oraz za granicą. Jej nakład wynosi 10000 egzemplarzy, a publikacje w niej zamieszczane często wykorzystywane są przez rosyjskie media jako cenne źródła informacji. „Islam Minbare” nie jest jednak jedynym wydawnictwem prasowym skierowanym do społeczności muzułmańskiej w Rosji.

W 2007 roku swoją działalność oficjalnie rozpoczął Dom Wydawniczy Medyna, który obecnie jest jednym z najszybciej rozwijających się wydawnictw muzułmańskich w Rosji. Został on utworzony przy wsparciu Duchownego Zarządu Muzułmanów Niżnego Nowogrodu i specjalizuje się w wydawaniu dzieł z zakresu współczesnej teologii muzułmańskiej, głównie szkoły hanafickiej ${ }^{31}$. W ramach wydawnictwa prowadzone są także badania na temat historii narodu tatarskiego, a także studia poświęcone dialogowi międzykulturowemu i międzyreligijnemu. Dom Wydawniczy Medyna stawia sobie za cel popularyzację kultury muzułmańskich narodów Rosji. Od roku 2004 zaczął się ukazywać miesięcznik „Medyna al-

\footnotetext{
${ }^{26}$ Tamże.

27 В Издательском доме «Медина» вышла газета «Ислам Минбаре», http://www. idmedina.ru/news/?2255 [dostęp: 25.11.2015].

${ }^{28}$ Tamże.

${ }^{29}$ Mintimer Szajmijew - pierwszy prezydent Republiki Tatarstanu, pełniący urząd w latach 19912010 .

${ }^{30}$ Kamil Ishakow - stały przedstawiciel Federacji Rosyjskiej przy Organizacji Konferencji Islamskiej w latach 2008-2011, mer miasta Kazań w latach 1989-2005.

${ }^{31}$ Издательский дом «Медина», http://www.idmedina.ru/medina/ [dostęp: 25.11.2015].
} 
Islam", co stało się punktem wyjścia do utworzenia samego wydawnictwa. W ciągu kilku miesięcy oferta wydawnicza wzbogaciła się o kolejne tytuły, wśród których na uwagę zasługuje zwłaszcza miesięcznik „Minaret”, będący - według zapewnień wydawcy - pierwszym periodykiem na rynku rosyjskim, poświęconym w całości muzułmańskiej doktrynie. W ciągu pierwszych dwóch lat działalności wydawnictwa ukazało się około stu tytułów ${ }^{32}$, co niewątpliwie jest imponującym wynikiem. W 2009 roku Dom Wydawniczy Medyna został wyróżniony przez Radę Muftich Rosji za wkład w rozwój myśli muzułmańskiej i aktywną działalność wydawniczą na terenie Federacji Rosyjskiej ${ }^{33}$.

Od kilku lat nakładem Domu Wydawniczego Medyna ukazują się regularnie dwa wiodące tytuly tego wydawnictwa: „Medyna al-Islam” i „Minaret”. Pierwszy swą formą jest bardzo zbliżony do „Islam Minbare”; również informuje o najważniejszych wydarzeniach, podejmuje aktualną tematykę, stara się przedstawiać opinie uczonych i prezentuje wywiady z wpływowymi osobistościami rosyjskiej społeczności muzułmańskiej. „Medyna al-Islam” w odróżnieniu od "Islam Minbare" nie ogranicza się jednak tylko do opisywania rzeczywistości rosyjskiej ummy, ale podejmuje także problematykę międzynarodową - informuje o wydarzeniach, jakie mają miejsce w krajach arabskich i państwach WNP. „Medyna al-Islam” ma również nieco bardziej analityczny charakter niż „Islam Minbare". Co ważne, elektroniczną wersję gazety każdy czytelnik może pobrać na swój komputer bezpłatnie wprost ze strony internetowej wydawnictwa w formie PDF. Papierową wersję „Medyna al- Islam” można natomiast nabyć w prawie 80 regionach Rosji i państwach WNP, również bezpłatnie. Nakład gazety wynosi 30000 egzemplarzy, a więc trzykrotnie przewyższa pod tym względem „Islam Minbare”"34. Drugim, regularnie ukazującym się tytułem wydawnictwa jest miesięcznik „Minaret”. Periodyk ten ma charakter popularno-naukowy i - podobnie jak wcześniejsze - jest wydawnictwem niekomercyjnym. Twórcy miesięcznika za główny cel stawiają sobie propagowanie wiedzy o tradycyjnym dziedzictwie wiary muzułmańskiej, a także jej wyjaśnianie w kontekście współczesności. Publikują artykuły poświęcone muzułmańskiej teologii, historii islamu i współczesnym problemom muzułmanów; piszą o życiu i działalności wybitnych muzułmańskich osobistości oraz myślicieli, publikują thumaczenia różnorodnych książek i artykułów, poruszają tematy dialogu międzyreligijnego i relacji organizacji muzułmańskich w władzami państwowymi. Grupą

\footnotetext{
${ }^{32}$ Tamże.

33 ИД «Медина» награжден почетной грамотой за активную книгоиздательскую деятельность, http://www.idmedina.ru/news/?1669 [dostęp: 25.11.2015].

34 Электронная версия газеты «Медина аль-Ислам» выложена на сайте ИД «Медина», http://www.tatar-inform.ru/news/2010/03/21/210811/ [dostęp: 25.11.2015].
} 
docelową, do której skierowany jest miesięcznik „Minaret”, są przede wszystkim dobrze wykształceni muzułmanie ${ }^{35}$.

Od 2008 roku ukazuje się także czasopismo „Muzułmanka” skierowane specjalnie dla kobiet. Publikowane są w nim artykuły poświęcone różnym aspektom życia współczesnych kobiet muzułmańskich, obejmujące kwestie religijne, społeczne oraz związane z psychologią. Każde wydanie składa się z określonych bloków tematycznych, takich jak: reportaże z Rosji i zagranicy, wywiady, blok teologiczny, porady związane $\mathrm{z}$ wychowaniem dzieci oraz rozwiązywaniem problemów rodzinnych, doniesienia z życia rosyjskiej ummy oraz przegląd wydarzeń kulturalnych w Rosji i świecie islamu. Oddzielną część pisma stanowi blok poświęcony modzie. Zamieszczane są w nim informacje o aktualnych trendach w świecie mody muzułmańskiej, przegląd najciekawszych marek sezonu, a także porady stylistów. W 2014 roku czasopismo „Muzułmanka” otrzymało główną nagrodę podczas Moscow Halal Expo w kategorii media i wydawnictwa. „Muzułmanka” wydawana jest w głównej mierze ze środków Rady Muftich Rosji ${ }^{36}$.

Niezwykle ciekawym wydarzeniem kulturalnym muzułmańskiej społeczności w Rosji jest odbywający się każdego roku w Moskwie Międzynarodowy Konkurs Recytatorów Koranu. Konkurs odbywa się regularnie od 2000 roku, a organizuje go Rada Muftich Rosji przy wsparciu sekretarza generalnego Organizacji Konferencji Islamskiej. W początkowej fazie wydarzenie to było skierowane tylko do absolwentów moskiewskich medres, jednak każdego roku cieszyło się coraz większym zainteresowaniem wśród społeczności muzułmańskiej, stąd począwszy od 2008 roku impreza ta ma charakter międzynarodowy, a od 2010 odbywa się pod egidą UNESCO. W 2015 roku odbyła się już XVI edycja tego wydarzenia, w którym udział wzięli uczestnicy z 44 krajów. Ostatecznie zwycięzcą ostatniej edycji został przedstawiciel Iranu, drugie miejsce zajął uczestnik z Jemenu, a trzecie przedstawiciel Tanzanii ${ }^{37}$.

Jednym z najważniejszych wydarzeń muzułmańskich z pogranicza biznesu, mediów i kultury, jakie odbywają się w rosyjskiej stolicy, jest międzynarodowa wystawa Moscow Halal Expo. W dniach 21-22 maja 2015 roku odbyła się już VI edycja tego wydarzenia. Głównym organizatorem tej imprezy jest Rada Muftich Rosji, a współorganizatorami są: Ministerstwo Spraw Zagranicznych, Ministerstwo Rozwoju Przemysłu i Handlu oraz Ministerstwo Rozwoju Regionalnego Federacji Rosyjskiej i władze Moskwy. Idea zorganizowania najwięk-

\footnotetext{
35 «Минарет»-журнал исламской доктрины, http://www.idmedina.ru/books/history_culture/ ?107 [dostęp: 25.11.2015].

${ }^{36}$ Редакция, http://musulmanka.ru/images/tech/vizitka.pdf [dostęp: 25.11.2015].

${ }^{37}$ Победителем XVI Московского Международного конкурса чтеиов Корана стал участник из Ирана, http://www.islamrf.ru/news/russia/rusnews/37859/ [dostęp: 25.11.2015].
} 
szej w Rosji wystawy przemysłu halal wraz z różnorodnymi imprezami towarzyszącymi zrodziła się w 2004 roku wśród pracowników Departamentu Międzynarodowego Rady Muftich Rosji. Organizatorów Moscow Halal Expo do zorganizowania takiej wystawy zainspirowała podobna, znana na całym świecie i odbywająca się co roku w Malezji - Malaysia International Halal Showcase. Chociaż podobne wystawy odbywają się w różnych zakątkach świata (m.in. w Iranie, Francji czy Pakistanie), to moskiewska impreza ma charakter wyjątkowy. Moscow Halal Expo nie ogranicza się jedynie do pokazu towarów i usług odpowiadających normom islamu. W jej trakcie poruszane są także zagadnienia muzułmańskich mediów, turystyki, czy działalności wydawniczej. Ponadto mają miejsce liczne sympozja i fora poświęcone aktualnym problemom rozwoju muzułmańskiego biznesu, zarówno w obszarze przemysłu halal, jak i finansów ${ }^{38}$. Moskiewska wystawa nie jest tylko wydarzeniem biznesowym, lecz jest to swego rodzaju święto dla rosyjskich muzułmanów, którzy pojawiają się na wystawach $\mathrm{z}$ całymi rodzinami.

Rosnąca liczba ludności muzułmańskiej w Rosji sprawia, iż nieuniknione jest również rosnące zaangażowanie wyznawców tej religii w życiu społecznym, politycznym oraz kulturalnym kraju. Postępujące zmiany społeczne sprawiają, że obecność muzułmanów w sferze publicznej i mediach staje się w ostatnich latach coraz bardziej zauważalna. Muzułmanie w Rosji dysponują własnymi kanałami telewizyjnymi, prasą, specjalistycznymi wydawnictwami, aktywnie działają w Internecie, a co najważniejsze są inicjatorami wielu ważnych wydarzeń kulturalnych, przez co przyczyniają się do wzrostu znaczenia rosyjskiej ummy. Aktywność rosyjskiej społeczności muzułmańskiej w sferze medialnej i kulturze jest jednym z rezultatów odrodzenia religijnego w Rosji. Różnorodne przedsięwzięcia zarówno medialne, jak i kulturalne, służyć mają nie tylko dostarczaniu rzetelnej wiedzy na temat islamu i życia muzułmanów w Rosji, lecz również mają niwelować negatywny wizerunek tejże społeczności wśród społeczeństwa rosyjskiego.

\footnotetext{
${ }^{38}$ Описание выставки, http://www.halalexpo.org/ru/doc/generalinfo/description/ [dostęp: 25.11.2015].
} 


\section{Bibliografia}

Krukowski J., Konstytucyjne modele stosunków między państwem a Kościołem w Europie, http:// www.pan-ol.lublin.pl/biul_9/art_907.htm.

Riasanovsky N.V., Steinberg M.D., Historia Rosji, Wydawnictwo Uniwersytetu Jagiellońskiego, Kraków 2009.

Roszczyn M., Islam w Rosji: umma dopiero się rodzi, „Nowa Europa Wschodnia”, 2013, nr 3-4 (XXIX-XXX).

Асадуллин Ф., Ислам в Москве, Логос, Москва 2006.

В России начал вещание первый общественный мусульманский телеканал, http://lenta.ru/ news/2012/08/20/alrtv/.

Гайнутдин Р., Ислам в современной России, ФАИР-ПРЕСС, Москва 2004.

ИД «Медина» награжден почетной грамотой за активную книгоиздательскую деятельность, http://www.idmedina.ru/news/?1669.

Издательский дом «Медина», http://www.idmedina.ru/medina/.

Казанский международный фестиваль мусульманского кино, http://kazan-mfmk.com/about$\mathrm{mfmk}$

Малашенко А., Ислам для России, Московский Центр Карнеги, Москва 2007.

Малашенко А., Филатов С., Двадиать лет религиозной свободы в России, Московский Центр Карнеги, Москва 2009.

Мамиргов 3., ТВК ,,Исламский Мир” (islamtv.ru), http://www.islamtv.ru/ about. html

Мусульмане, http://russia.tv/brand/show/brand_id/3959/.

Описание выставки, http://www.halalexpo.org/ru/doc/generalinfo/description/.

Победителем XVI Московского Международного конкурса чтецов Корана стал участник из Ирана, http://www.islamrf.ru/news/russia/rusnews/37859/.

Редакичия, http://musulmanka.ru/images/tech/vizitka.pdf.

Электронная версия газеты «Медина аль-Ислам» выложена на сайте ИД «Медина», http://www.tatar-inform.ru/news/2010/03/21/210811/.

\section{Muslims in contemporary Russia: mass media and culture}

The article analyzes growth, activity and influence of Russian Muslim community in Russian Federation, especially regarding media and culture. The author points out, that this group is becoming more and more numerous, influential and important, and that its growth should be considered as one of the most significant outcomes of the religious „renaissance” in Russia.

Keywords: Islam, Russia, Muslim community, culture, mass media, religions in Russia 